\title{
Australian Citreae with notes on other Aurantioideae (Rutaceae)
}

\author{
D.J. Mabberley
}

\begin{abstract}
Mabberley, D.J. (Rijksherbarium, University of Leiden, Netherlands and Royal Botanic Gardens Sydney, Mrs Macquaries Road, Sydney, NSW, Australia 2000) 1998. Australian Citreae with notes on other Aurantioideae (Rutaceae). Telopea 7(4):333-344. Both subtribes of tribe Citreae (Rutaceae: subfam. Aurantioideae) are represented in Australia: the sole representative of 'Triphasiinae' is here referred to Luvunga Wight \& Arn., in which the new combination, L. monophylla (D.C.) Mabb., is proposed, and the relationships of the Australian Citrineae to the genus Citrus L. are reassessed; Eremocitrus Swingle and Microcitrus Swingle are reunited with Citrus. A new species, C. gracilis Mabb. from the Northern Territory, is described and a conspectus of, and an identification key to, Australian native Citrus spp. presented; 'Sydney Hybrid' is formally described and named C. $\times$ virgata Mabb.; a new combination, C. $\times$ floridana (J. Ingram \& H. Moore) Mabb., for the name of the limequat and a new name, C. wintersii Mabb., for one of the Papuan endemic species formerly referred to Microcitrus are proposed. In tribe Clauseneae, notes on Glycosmis, Micromelum and Murraya, especially on typification of names, are presented.
\end{abstract}

\section{Rutaceae: Aurantioideae in Australia}

This paper is a prelude to the account of the subfamily Aurantioideae Horan. for Flora of Australia, in which full descriptions will be found, so those are not repeated here. The subfamily in its wild state is restricted to the tropics and subtemperate parts of the Old World and comprises two tribes: Clauseneae Wight \& Arn. and Citreae Meissner, both of which are represented in Australia. Native Clauseneae are species of Clausena Burm.f., Glycosmis Correa, Micromelum Blume and Murraya L. (see Appendix); Citreae are represented by species referred to two of the three subtribes recognised by Swingle (1944: 136-7), viz. Triphasiinae Swingle (apparently not validly published) and Citrineae Engl.

It is worth noting here that the traditionally used subfamily name for this assemblage was validly published in 1847 (I am greatly indebted to Jim Reveal for pointing this out):

Rutaceae Juss. subfam. Aurantioideae Horan., Char. Ess. Reg. Veg.: 203 (1847 as 'Aurantiaceae', sub Meliaceae)

Aurantiaceae Juss., Gen. Pl.: 260 (1789).

Type: Aurantium Tournef. ex Miller (= Citrus L.)

Linnaeus (see references under account of Citrus, below) combined Tournefort's genera Aurantium (oranges), Citreum (citrons) and Limon (lemons) as his new genus Citrus, a name used in Classical Latin for Tetraclinis articulata (Vahl) Masters (Cupressaceae), a North African tree with fragrant timber. The type species of Citrus L. is C. medica L., the citron. In reviving Tournefort's genera, Miller effectively split up Citrus, with Aurantium and Limon being legitimate names and Citreum a superfluous renaming of Citrus. Suprageneric names based on Aurantium Tournef. ex Miller are therefore legitimate. 


\section{Australian 'Triphasiineae'}

The sole Australian representative of the subtribe was collected in the Sir Edward Pellew Group, Gulf of Carpentaria, in December 1802 by Robert Brown during Flinders's Investigator circumnavigation of Australia; further material was gathered a few months later in Timor by J.B.L.C.T. Leschenault de la Tour on Baudin's voyage. The first gathering was the basis for Atalantia (?) recurva Benth. (1863) but the second was described long before as Triphasia monophylla DC. (1824). Currently (Pedley 1987), the plant, which is native in Java and the southern Philippines too, is referred to Paramignya Wight as P. trimera (Oliver) Burkill ( $P$. monophylla is another species). Swingle (1944: 254) considered P. trimera 'aberrant' in Paramignya because of its trimerous flowers and other features. The genus Luvunga Wight \& Arn. was held to differ from Paramignya in its 3-5 petals, 6-10 stamens and 2-4 locules in the ovary, so that $P$. trimera is more logically placed in Luvunga. The simple leaves characteristic of Paramignya, including P. trimera, sometimes occur in Luvunga: in those cases, the leaves have petioles shorter than those of the usual trifoliolate leaves, and very closely resemble the leaves of Paramignya species. Swingle, following earlier authors, notably Oliver, considered that the two genera were extremely close; further study of Malesian species may lead to their complete amalgamation.

Luvunga monophylla (DC.) Mabb., comb. nova

Triphasia monophylla DC., Prod. 1: 536 (1824)

Type: Timor: Anon. (ex herb. Paris 1821 [J.B.L.C.T. Leschenault de la Tour, 1803]); holo: G-DC (fiche seen); iso: K ['Leschenault'], L ['ex herb. Paris']

Atalantia trimera Oliver, J. Proc. Linn. Soc. Bot. 5, suppl. 2: 24 (1861), non A. monophylla DC.

Paramignya trimera (Oliver) Burkill, Gard. Bull. Straits Settlem. 5: 213 (1931), non P. monophylla Wight.

Atalantia (?) recurva Benth., Fl. Austral. 1: 370 (1863).

Type: Australia: Gulf of Carpentaria, Sir Edward Pellew Group, 18 Dec. 1802, R. Brown s.n. [Bennett 5342]; lecto (selected here): K (annotated by Bentham); isolecto: BM.

\section{The generic problem in Citrineae}

The species of the subtribe Citrineae are unique in bearing orange- or lemon-shaped fruits with pulp-vesicles filling all the space in the segments of the fruit not occupied by seeds. These pulp-vesicles are the basis for the most important fruit industry in warm countries, for, in species and hybrids of Citrus subg. Citrus, they contain potable juice of great commercial significance.

Within the subtribe, Swingle (1944: 340) called Citrus and five other genera the 'True Citrus Fruit Trees', all except Clymenia with slender-stalked pulp-vesicles. Most of the genera had been segregated from Citrus by Swingle himself: Clymenia Swingle, Eremocitrus Swingle, Fortunella Swingle, Microcitrus Swingle and Poncirus Raf. The group is represented by species from northern India to northern China, through Malesia to eastern Australia. Citrus sensu stricto is found throughout this range, except in northern China (where Poncirus, 1(? or $2 \mathrm{spp}$, the second possibly a hybrid with Citrus - cf. Swingle (1944: 373), but see below) is native) and Australia (the only representatives of the entire subtribe being, besides naturalised Citrus subg. Citrus, the endemic Eremocitrus (1 sp.) and Microcitrus (5 (4 endemic) of the seven known allopatric species plus one from the Northern Territory so far unnamed)). The two last genera have been shown to be very closely allied to one another by Barrett and Rhodes (1976); Swingle had already noted that they (though this has not been confirmed for 
all Microcitrus spp. now known) resembled one another in their dimorphic foliage and free stamens, such distinctive juvenile foliage not being found in Citrus and free stamens only in Citrus subg. Papeda (Hassk.) Swingle. Species of Citrus subg. Papeda have simpler floral vascular systems than do those of subg. Citrus and, in this regard, resemble species referred to the segregate genera which share the free stamens typical of this subgenus (though species of subg. Papeda 'sect. Papedocitrus' (an invalidly published name) have stamen-bases cohering as in subg. Citrus and in Fortunella). Swingle considered that Eremocitrus, like Fortunella, had 3-5(-7)-locular fruits with only two seeds per locule, Microcitrus resembling Citrus, Clymenia and Poncirus in having 6-8(-16)-locular fruits with 4-12 seeds per locule. Poncirus, like Eremocitrus, is deciduous but has trifoliolate leaves, though the range of trifoliolate to unifoliolate leaves is seen in other Citreae, e.g. Luvunga (see above).

Although apparently relatively unconsidered in experimental work, species of Citrus subg. Papeda, which have been hybridised with species in subg. Citrus, have petioles which are broadly winged and very large compared with those in subg. Citrus; the pulp vesicles contain globules of very acrid oil and are sometimes attached to the radial locule walls for half to three-quarters the distance from the dorsal wall to the centre of the fruit. Typical Clymenia has most vesicles attached to the radial walls of the locules; all the other genera have all or most vesicles attached to the dorsal walls. Oil droplets are abundant in the vesicles of Poncirus, Microcitrus and Citrus subg. Papeda, fewer in Clymenia (? fruits sweet), Eremocitrus and Fortunella besides Citrus subg. Citrus. Citrus halimii Stone (subg. Citrus, Thailand, Malay Peninsula, Borneo) approaches Fortunella in other respects (Stone et al. 1973 ) as does C. swinglei Burkill ex Harms (C. polyandra (Ridley) Burkill non Tanaka; Fortunella polyandra (Ridley) Tanaka; F. swinglei MSS) with 5-celled globose fruit and 2 ovules per locule. Moreover, Microcitrus garrawayae has 4-merous fruits (and M. papuana $\mathrm{H}$. Winters from $\mathrm{New}$ Guinea 3-5-merous) like Fortunella and Eremocitrus, while the new 'Microcitrus', from the Northern Territory, has much of the habit of Eremocitrus but the gynoecial structure of the first described Microcitrus species.

By the time of Swingle's monograph (1944), intergeneric hybrids had been raised between species from all genera except Clymenia (Bismarck Archipelago, though C. platypoda Stone described from New Guinea since then may actually be a natural Citrus-Clymenia hybrid (Stone 1985) and Microcitrus inodora, which is quite distinct from the other Australian M. spp. in its leaf-venation, resembling that in Clymenia, has also been hybridised with Eremocitrus (Rahman \& Nito 1994)) and successful intergeneric grafts made. This latter is of great importance as Tristeza Virus-resistant rootstocks from a number of allied taxa can be combined with susceptible scions of commercially important citrus.

The commercially important citrus are largely derived from three allopatric Citrus (subg. Citrus) spp.: C. medica L. (India), C. reticulata Blanco (China) and C. maxima (Burm.) Merr. (SE Asia), though there are at least two as yet unrecognised species in the ancestry of the lime, $C . \times$ aurantiifolia (Christm.) Swingle, and the lemon, $C . \times$ limon (L.) Osb. (see Mabberley 1997). One of these has been suggested to be a species of Microcitrus (Scora \& Kumamoto 1983), Barrett and Rhodes (1976) speculating that lime is a trihybrid involving that unknown species, C. medica and C. maxima (C. grandis). Rahman and Ito (1994) analysed the leaf isozymes of glutamate oxaloacetate transaminase in Citrus-Microcitrus crosses and concluded that the two 'genera' have very similar genetic systems and that the species of the two 'genera' are indeed very closely related to one another; moreover, they showed that common alleles at the three loci controlling GOT isozymes are found in genera of the 'True Citrus Fruit Trees', suggesting that a genetic identity is conserved among them, even those climatically, geographically and reproductively isolated. Vardi et al. (1989) fused Citrus and 
Microcitrus protoplasts and the resultant microcalli gave rise to embryos which grew into trees with Citrus morphology, though their mitochondria had novel DNA indicating recombination between the chondriomes of the two 'genera'. In the embryos their chloroplasts were from either or both parents, tending to sort out to one parental type as the trees matured.

If it should transpire that Microcitrus has indeed contributed to the genetic make-up of the lime, then, with Swingle's classification, the lime would have to be considered an 'intergeneric hybrid' unless Microcitrus be returned to Citrus once more. Such 'intergeneric hybrids' abound in this group and they include the commercially significant limequats, $\times$ Citrofortunella J. Ingram \& H. Moore (Citrus $\times$ Fortunella) in which the calamondin, an important ornamental, is accommodated; the (Troyer) citrange, $\times$ Citroncirus J. Ingram \& H. Moore (Citrus $\times$ Poncirus); and even some 'trigeneric' hybrids like citrangequats and citrangedins (Poncirus $\times$ Citrus $\times$ Fortunella) have been synthesised. Of native Australian species, Eremocitrus glauca has been crossed with lemon to give 'eremolemons' and with sweet orange to give 'eremoranges', which also have to be given 'intergeneric hybrid' status if Eremocitrus is kept distinct from Citrus; 'eremoranges' have also been involved in 'trigeneric' hybrids adding Poncirus to give 'citrangeremos' (Swingle 1944: 366). Swingle opines (p. 366), 'If it proves possible to cross-pollinate successfully a citrangeremo with another trigeneric hybrid already existing, the faustrimedin [= Microcitrus $\times$ (Fortunella $\times$ Citrus)], no fewer than 5 genera of True Citrus Fruit Trees will have been combined in the resulting hybrid, viz., Citrus, Fortunella, Microcitrus, Eremocitrus, and Poncirus! Naturally [sic!] such ultra-complex hybrids, if obtained, would not be recognised by taxonomists as constituting true genera or true species [!]'.

Long before the borders of these finely distinguished genera were so strikingly transgressed by discovery of new species and found to be increasingly indistinct by breeding and molecular work, Burkill (1931) re-united Swingle's genera (referring to them as "microgenera" with a narrowness which offends my conception of what a genus is'). In so doing, he obviated the necessity for the description of 'intergeneric' hybrids in this tight-knit group and he recognised Swingle's 'genera' at subgeneric level. Whether even subgenera are now worth recognising must await monographic work on Citrus for Flora Malesiana. However, in treating for Flora of Australia the calamondin cultivated on Christmas Island, Du Puy (1993) has already followed the lead of Hiroe (1974) in referring it to Citrus and not $\times$ Citrofortunella, re-amalgamating Fortunella with Citrus. Considering all the evidence now before us, there indeed seems to be no reasonable alternative to following them and Burkill. Although it is perhaps sad (at least for 'biodiversitimetricians'!) to see the 'loss' of an Australian 'endemic genus' (Eremocitrus) and regrettable to see the names of well-known cultivated plants change (back), the demise of hybrid mouthfuls resulting from an overenthusiastic splitting of a genus earlier this century will not, I suspect, be mourned for long. Indeed, the subtle distinctions between the Swingle 'microgenera' have not only long troubled botanists, but have baffled and confused commercial growers and amateur gardeners alike.

\section{Citrus indigenous in Australia}

A conspectus of the species in Australia, with notes on typification where appropriate, follows: full descriptions will be presented in the forthcoming Flora of Australia account. The cultivated species classically referred to Citrus have been covered by Mabberley (1997); other exotic species seen in Australia are:

*kumquats or cumquats: - cultivars of Citrus japonica Thunb. (Fortunella japonica (Thunb.) Swingle; including C. margarita Lour. (F. margarita (Lour.) Swingle) according 
to recent Japanese authors following T. Makino, Makino's New Illustrated Flora of Japan (1964: 339)).

*calamondin: C. $\times$ microcarpa Bunge

Type (?holotype): 'Chine boreal', Anon. in Herb. Bunge (P).

$[$ C. $\times$ mitis Blanco,$\times$ Citrofortunella mitis (Blanco) J. Ingram \& H. Moore,$\times$ C. microcarpa (Bunge) Wijnands, Citrus (F.) margarita $(=$ C. japonica, kumquat $) \times$ C. reticulata Blanco (mandarin)]

*limequat: Citrus x floridana (J. Ingram \& H. Moore) Mabb., comb. nova

$\times$ Citrofortunella floridana J. Ingram \& H. Moore in Baileya 19: 170 (1975).

Type: An illustration (J. Agric. Res. 23: 237 t. 4 (1923)) was cited as type by the authors.

[Citrus $\times$ aurantiifolia (Christm.) Swingle (lime) $\times$ C. (F.) japonica (kumquat); including $\times$ Citrofortunella swinglei J. Ingram \& H. Moore (non Citrus swinglei Burkill ex Harms ), i.e. Citrus margarita $(=$ C. japonica $) \times$ C. $\times$ aurantiifolia].

For discussion on the synthesis of limequats in F.W. Savage's citrus grove in Eustis, Florida, USA in 1909, see Swingle and Robinson (1923).

Whether the rather distinctive temperate Chinese Poncirus trifoliata (L.) Raf. (Citrus trifoliata L.), with deciduous trifoliolate leaves, and consequently $\times$ Citroncirus J. Ingram \& H. Moore (citrangors, citrandarins, citranges $[\times C$. webberi $]$. Ingram \& H. Moore, Citrus $\times$ hybrida hort.], citrangequats), should be re-amalgamated with Citrus (cf. Hiroe (1974)), awaits further work. However Fang and Zhang (1992) have already argued that P. polyandra S.Q. Ding, X.N. Zhang, Z.R. Bao \& M.Q. Liang, a species with evergreen trifoliolate leaves recently found in Yunnan, may be a 'missing link' between the two genera.

Citrus L., Sp. Pl. 2: 782 (1753)

Type: C. medica L.

[Citreum Tournef. ex Mill., Gard. Dict., abr. ed. 4: [383] (1754), nom. superfl. pro Citrus]

Eremocitrus Swingle, J. Agric. Res. 2: 86 (1914); Citrus L. subg. Eremocitrus (Swingle) Burkill, Gard. Bull. Straits Settlem. 5: 218 (1931).

Type: E. glauca (Lindley) Swingle = C. glauca (Lindley) Burkill

Microcitrus Swingle, J. Wash. Acad. Sci. 5: 570 (1915); Citrus L. subg. Microcitrus (Swingle) Burkill, Gard. Bull. Straits Settlem. 5: 219 (1931).

Type: M. australasica (F. Mueller) Swingle = C. australasica F. Mueller

Fortunella Swingle, J. Wash. Acad. Sci. 5: 167 (1915); Citrus L. subg. Fortunella (Swingle) Burkill, Gard. Bull. Straits Settlem. 5: 218 (1931).

Type: F. margarita (Lour.) Swingle $=$ C. japonica Thunb.

$\times$ Citrofortunella J. Ingram \& H. Moore in Baileya 19: 169 (1975).

Type: not indicated.

Six species (five endemic) are native in Australia. 


\section{Key to identification}

1. Leaves $8-20 \times 4-10 \mathrm{~cm}$ with numerous lateral veins; spines often paired

1. C. inodora

1. Leaves $1.5-6(-9) \times 0.4-3 \mathrm{~cm}$ without numerous lateral veins; spines solitary

2. Leaves ovate to rhombic 3

3. Fruits ovoid to ellipsoid

2. C. garrawayae

3. Fruits cylindric-fusiform

3. C. australasica

3. Fruits globose

4. C. australis

2. Leaves narrowly ovate to sublinear 4

4. Leaves not coriaceous, glabrous; locules 8 or 9 5. C. gracilis

4. Leaves coriaceous, adpressed grey-hairy; locules 3 6. C. glauca

1. Citrus inodora F.M. Bailey, Rep. New Plants: $1(1889)^{*}$ as C. inodorus

Type: Queensland: Russell R., Harvey's Creek, F.M. Bailey s.n.; holo: BRI, n.v.; ?iso: K. Microcitrus inodora (F.M. Bailey) Swingle, J. Wash. Acad . Sci. 5: 577 (1915).

C. maideniana Domin, Bibl. Bot. 89: 297 (1927); M. maideniana (Domin) Swingle, J. Wash. Acad. Sci. 28: 533 (1938).

Type: Queensland: Russell R., Harvey's Creek, K. Domin 5602; holo: PR.

Russell River lime, North Queensland lime; Queensland (Cook District).

2. Citrus garrawayae F.M. Bailey, Qld. Agric. J. 15: 491 (1904) as C. garrawayi

Type: Queensland: Cape York Peninsula, Mt White near Coen, May 1904, R.W. Garraway s.n.; holo: BRI, n.v.; iso: P.

Microcitrus garrawayae (F.M. Bailey) Swingle, J. Wash. Acad. Sci. 5: 574 (1915) as 'M. garrowayi'.

[M. australasica sensu Stone, Proc. Acad. Nat. Sci. Philadelphia 137: 226 (1985) p.p. (cf. P.I. Forster, Telopea 4: 357, 1991)]

Mount White lime. Queensland (Cape York Peninsula), New Guinea (Goodenough Is.)

3. Citrus australasica F. Mueller, Fragm. Phytogr. Aust. 1: 26 (1858)

Type: Queensland: Moreton Bay, W. Hill s.n.; holo: MEL.

Microcitrus australasica (F. Mueller) Swingle, J. Wash. Acad. Sci. 5: 572 (1915)

?Citrus cataphracta W. Hill, Queensland Timbers: 23 (1880) e descr.

Type: not preserved?

Finger lime; southern Queensland, northern New South Wales.

This has been crossed not only with C. australis (q.v.) but also with the calamondin (C. $\times$ microcarpa Bunge) to give the faustrimedin (Swingle 1944: 360)

*Oct 1889 (fide A.D. Chapman, Austr. Pl. Name Index A-C: 730 (1991), n.v.; Bailey in Meston, Rep. Bellender-Ker Range [ Votes \& Proc. Legisl. Ass. Qld 1889, 4]: 15 (post 7 Oct 1889) \& Bailey, Bot. Bellenden-Ker Exped.: 34 (1889), both as C. inodorus. 
4. Citrus australis (Mudie) Planchon, Hort. Donat.: 18 (1858)

Limonia ? australis A. Cunn. ex Mudie, Pict. Austral.: 151 (1829)

L. australis A. Cunn. ex Mudie, Veg. Subs.: 420 (1829)

Type: Queensland: Moreton Bay, 1829, A. Cunningham '26'; lecto (chosen here): BM; isolecto: $\mathrm{K}$.

Microcitrus australis (Mudie) Swingle, J. Wash. Acad. Sci. 5: 575 (1915).

[C. planchonii F. Mueller, Austral. Veg.: 23 (1867) nom. nud.; Fragm. Phytogr. Aust. 9: 105 (1875), nom. superfl. pro C. australis]

Australian lime, dooja; southern Queensland.

Mudie described fruiting material (the fruit shaped like that of a lime [unlike that of the finger-lime, M. australasica, with which it might otherwise have been confused]) sent by Allan Cunningham, quoted from Cunningham's letters (Mabberley 1992) and attributed the name Limonia australis to him. Mudie seems to have had access to this information through his contacts at Kew, for Cunningham sent living material with some of black bean, Castanospermum australe A. Cunn. ex Mudie (Leguminosae/Fabaceae) to William Townsend Aiton there on board the George Canning 12 March 1829 (Mabberley 1992). As with the black bean, there is in the Drawings Collection at Kew a watercolour (by George Bond [Desmond 1995:218]) of a seedling ('26', '1041'). It is annotated 'Received in 1829 from Mr Cunningham discovered by him at Moreton Bay, east Coast of New South Wales...Limonia australis C.' in the same hand as that on the label attached to a Cunningham specimen now at BM (whither Robert Brown removed such material prior to the takeover of Kew by William Jackson Hooker [Desmond 1995: 155]); that sheet is also annotated '26' and, apparently in Cunningham's hand, 'Limonia australis'. This then links to Mudie and is here designated lectotype. Swingle (1944: 380) typified 'Citrus australis Planch.' with a Leichhardt sheet in Paris but there is no evidence Mudie saw this material, which was also collected at Moreton Bay.

Citrus australis has allegedly been hybridised with C. australasica to give 'Sydney hybrid' (Swingle 1944: 382).

\section{Citrus $\times$ virgata $M a b b$., hybr. nova}

Hybrida hortensis e C. australasica F. Muell. et C. australe (Mudie) Planchon exorta, inter parentes media, sed virgis numerosis, puberulis, fructibus elongato-obovoideis vel ellipsoideis.

Typus: Cultivated in USDA greenhouses, Washington DC, USA, 'C.P. \& B. no. 7775-E', 23 Oct. 1939, W.T. Swingle s.n.; holo: NSW.

['Microcitrus hybrid' Winston et al., J. Agric. Res. 30: 1092 (1925)]

[Microcitrus x virgata H. Hume, Cult. Citrus Fruit : 31, t. 38 f. 19 (1926), pro sp., nom. nud.; Klotz \& Fawcett, J. Agric. Res. 41: 420 (1930), pro sp., nom. nud.]

According to Swingle (1944: 382, q.v. for full description), the plant was raised from seed sent to USDA's Agricultural Research Service by J.H. Maiden, Director of the Sydney Botanic Gardens, 'Before its hybrid nature had been established, this form [sic] was called ... Microcitrus virgata, a provisional name alluding to its very numerous slender, straight, whiplike twigs ... More than 200 meters of twigs both large and small, were borne on a single branch, $3 \mathrm{~cm}$ in diameter, of a Sydney hybrid growing near Riverside, California, which survived for several decades on land no longer irrigated where citrus trees made little or no growth'. There is a plant in the Royal Botanic Gardens Sydney today, but I have been unable to establish when or from whom it was received or whether it, too, was grown from Maiden's seeds; it is also 
unclear when Maiden sent seeds to Swingle or whether he had deliberately made the cross.

Material from Swingle's stock can be called C. $\times$ virgata 'Sydney Hybrid'. According to Stephen Sykes of CSIRO (pers. comm.), 'Sydney Hybrid' has been successfully crossed, as the male parent, with clementine (C. reticulata $\mathrm{cv}$.)

\section{Citrus gracilis $M a b b$., sp. nova}

C. wintersii Mabb. (Microcitrus papuana Winters) simulans, a qua imprimis differt ovariis 8- vel 9-loculatis, hesperidiis sphaericis ad $7 \mathrm{~cm}$ diam.

Typus: Australia: Northern Territory: 5 miles [c. 8 km] W of Humpty Doo, J. McKean B19; holo: NSW, iso: CANB, DNA.

Armed straggling tree to $4 \mathrm{~m}$ high, often coppicing and suckering; bark cracking into irregular squares. Leafy twigs c. $2 \mathrm{~mm}$ diam., terete, fawn-pubescent when young; spines to c. $12 \mathrm{~mm}$ long, solitary. Leaves c. $4-6(-9) \mathrm{cm}$ long, lamina to c. $4.5(-7) \times 1.1(-2)$ $\mathrm{cm}$, narrowly ovate to lanceolate or oblanceolate, those subtending young twigs with narrow leaves sometimes ovate, those on suckers often subsessile, smaller and much narrower (to sublinear), apex acute, base acute to cuneate, margin sometimes distally

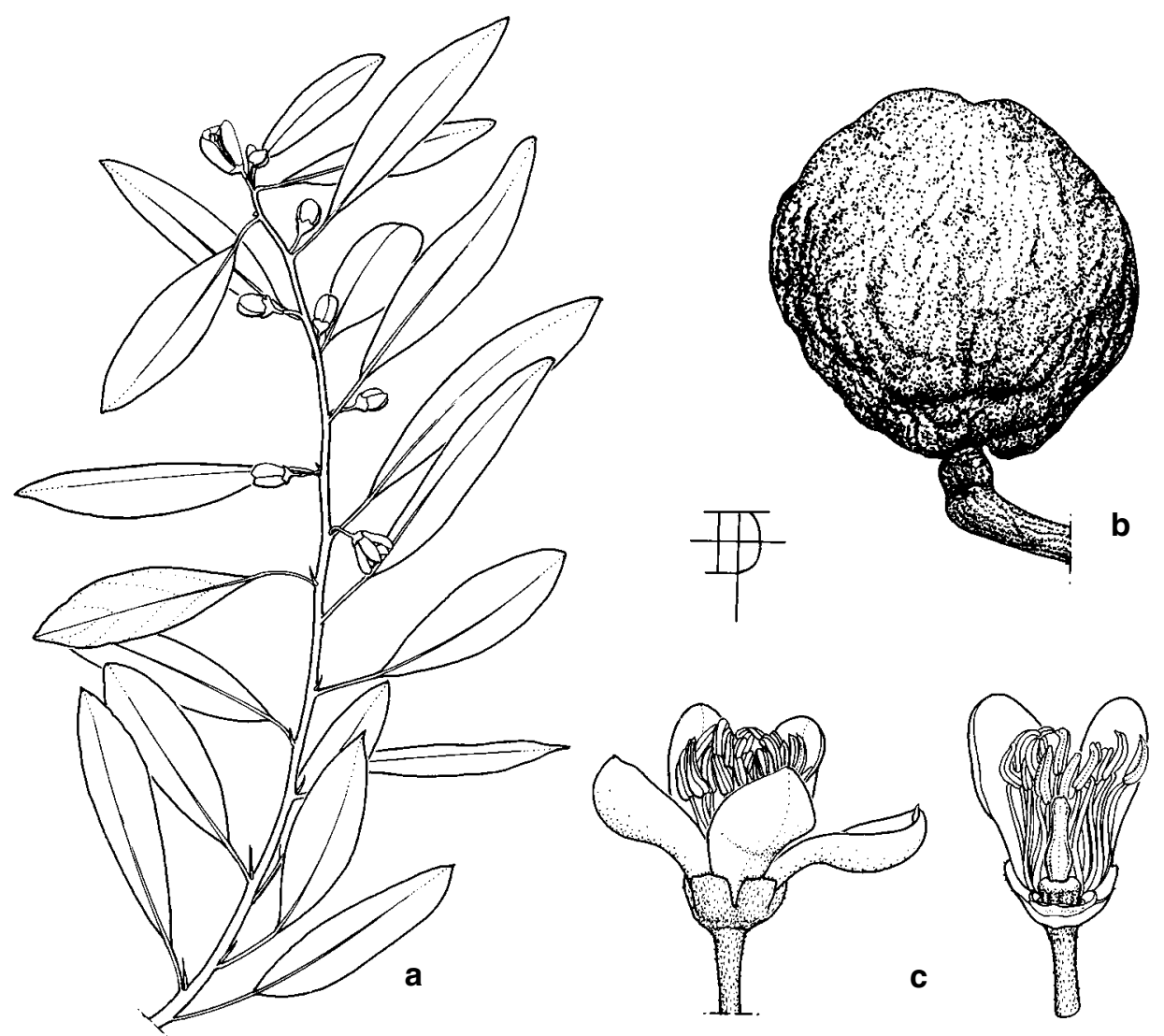

Fig. 1. Citrus gracilis Mabb. a, flowering twig $(\times 0.9)$. b, flowers (? functionally male; $\times 3.6)$. c, fruit ( $\times$ 0.67). (a, b from T.G. Hartley et al. 15142. c, from J. Tiddy s.n., May 1984). (Drawing by Don Fortescue, reproduced with kind permission of T.G. Hartley). 
subcrenulate, costae c. 6 on each side, acute; petiole c. 3-15 mm long, in largest leaves sometimes clearly articulated at base of lamina. Flowers usually solitary, rarely in fascicles of 3, subsessile or with finely hairy pedicel up to c. $3 \mathrm{~mm}$ long. Calyx c. $2 \mathrm{~mm}$ long, $3.5 \mathrm{~mm}$ across, salveriform to cupular, 5-lobed, subglabrous to finely hairy without, lobes truncate to acute or mucronate, margins ciliate. Petals c. $8 \mathrm{~mm}$ long, $4 \mathrm{~mm}$ wide, obovate, cucullate, pinkish white, apex rounded to acute. Stamens 26-30, c. $7 \mathrm{~mm}$ long; anthers c. $2 \mathrm{~mm}$ long. Disk c. $1.5 \mathrm{~mm}$ across, cushion-shaped. Pistil c. $4 \mathrm{~mm}$ long, stout, 8- or 9-ribbed basally (though sometimes scarcely developed -? pistillode), with a few hairs near apex; ovary 8- or 9-locular. Fruit c. $8 \mathrm{~cm}$ diam., globose. Fig. 1.

Eucalypt woodland with grassy understorey on sandy or gravelly soils. Fruits said to be eaten by Aboriginal people.

Other material seen: Northern Territory: Howard Springs Hunting Reserve, 350m S of NE Corner, S.M. Taylor 142, 146 (DNA); Sawyer Road near Howard Springs, G. Leach \& L. Tumbilis 3907 (DNA); Harrison Dam, 4 Oct 1988, J. Cusack s.n. (CANB); Kakadu, Kapalga Station, I. Cowie 704 (DNA), J. Cusack et al. 3094 (FHO), T.G. Hartley et al. 15142 (CANB, FHO); $1.5 \mathrm{~km} \mathrm{~W}$ Twin Point North, C.R. Dunlop \& J. Cusack 7925 (DNA); Arnhem Land, Maningrida-Oenpelli road, M.J. Clark 1332 (DNA); 2 km E of Oenpelli, May 1984, J. Tiddy s.n. (CANB); Marrakai, Mt Bundy Road, D.A. Hearne 194 (BRI, CANB); Peppimenarti, 12 Mar 1993, K. Reynolds s.n. (DNA).

The type specimen is apparently the first collection (1971). The specific epithet refers to the graceful aspect of the flowering twigs. Superficially resembling $C$. wintersii Mabb. (see below) in its narrow leaves, it differs from that New Guinea endemic in not having cylindrical fruits; from the other New Guinea endemic, C. warburgiana, with which some forms share the broader leaves characteristic of many specimens of that species, it differs in its much larger fruit as it also does from C. glauca, which also has narrow leaves and suckering spiny shoots. The characteristic large fruits with many locules also point up the artificiality of any system maintaining Microcitrus as a genus distinct from Citrus.

Whether the occurrence of pistillodes indicates dioecy or plants with hermaphrodite and functionally male flowers remains to be ascertained: without field studies this can only be investigated by unacceptable destructive sampling of herbarium material. It is to be noted that non-fruiting forms of $C$. glauca have been recorded and that both male and hermaphrodite flowers are known from individual cultivated citrus trees, indicating that the breeding system in C. gracilis may not be unique to that species.

6. Citrus glauca (Lindley) Burkill*, Gard. Bull. Straits Settlem. 5, Index: 3 (1932)

Triphasia glauca Lindley in Mitchell, J. Exped. Trop. Austral.: 353 (1848)

Type: [Queensland: Dublin County near junction of Maranoa \& Merivale Rivers,]17 Oct. 1846, 'Tastes like Rue', T.L. Mitchell 398; holo: CGE (transparency seen); iso: BM, K, L ['subtropical New Holland 1846'].

Atalantia glauca (Lindley) Benth., Fl. Austral. 1: 370 (1863)

Eremocitrus glauca (Lindley) Swingle, J. Agric. Res. 2: 88 (1914)

Atalantia glauca var. inermis Bailey, Qld. Agric. J. II, 3: 29 (1915)

Syntypes: Queensland, near Dalby, Sept 1913, T.C. Bancroft s.n. (BRI, n.v.); Chinchilla, Dec. 1914, R.C. Beasley s.n. (BRI, n.v.).

Limebush, Australian desert lime, wild lime, native lime, desert kumquat; Queensland, New South Wales, South Australia.

Hybrids between C. glauca and C. japonica, C. medica, C. $\times$ aurantium and C. $\times$ aurantiifolia have been raised but those with the last set no seed and those with $C$. medica died when small (Barrett 1978). 
*Name not in Index Kewensis or other works.

\section{Non-Australian 'Microcitrus'}

The two non-Australian species formerly referred to Microcitrus are restricted to New Guinea.

1. Citrus warburgiana F.M. Bailey, Contrib. Fl. Brit. New Guinea: [1] + tab. (1902)

Type: Papua New Guinea: Gibara, Milne Bay, W.E. Armit s.n.; holo: BRI, iso: P.

Microcitrus warburgiana (F.M. Bailey) Tanaka, Bull. Soc. Bot. France 75: 714 (1928)

\section{Citrus wintersii Mabb., nomen novum}

Microcitrus papuana H. Winters, Baileya 20: 19 (1976), non C. papuana F.M. Bailey (= C. macroptera Montr.).

Type: Papua New Guinea: Central Dist., Brown River Forest Station, H.F. Winters E J.J. Higgins 763; holo: NA, n.v.; iso: L.

'Brown River finger lime'. South-eastern Papua New Guinea.

The new name commemorates Harold F. Winters of the USDA, Beltsville, who first described the plant. Fertile hybrids between C. wintersii and C. glauca as well as between it and C. japonica and also Poncirus trifoliata have been raised in USA (Winters 1976).

\section{Notes on Tribe Clauseneae Wight \& Arn.}

1. Glycosmis macrophylla (Blume) Miq.

The type of Sclerostylis ?macrophylla Blume, Bijdr.: 135 (1825), the basionym of G. macrophylla (G. sapindoides Lindl. ex Oliver), the name of a widespread Malesian species found in northern Western Australia and the Northern Territory, is given as Java. However, in Blume's herbarium at Leiden, the only sheet bearing his MS name for his new species is an unnumbered gathering collected by C.G.C. Reinwardt on Halmaheira in August 1821. It is here chosen as lectotype.

\section{Micromelum minutum (Forst. f.) Wight \& Arn.}

One of the synonyms of $M$. minutum, a common and widespread coastal tree of the Indopacific, is M. pubescens Blume, Bijdr.: 138 (1825) which was described from Java but has not, to my knowledge, been precisely typified. I here select from the Blume sheets at Leiden that with the binomial in Blume's hand (sheet HLB 908203-1854) as lectotype of M. pubescens.

\section{Murraya paniculata (L.) Jack}

This species, found throughout Indomalesia to New Caledonia and Australia, comprises a number of distinctive forms, one of which, probably domesticated in China, has been long and widely cultivated. In Australia, where it is one of the most commonly seen shrubs in older gardens in Sydney, for example, it is locally naturalised. This is the orange jasmine/jessamine or Chinese box, 'Murraya exotica', a form with rather small leathery leaflets and was the cultivated Camunium japonense of Rumphius's Herbarium amboinense (5:t. 18 f. 2, 1747). Rumphius contrasted it with the wild form on Ambon, his Camunium vulgare (Herb. Amb. 5: t. 17, 1747), which figure is the lectotype selected by Nair (Reg. Veg. 127: 32 (1993)) for Chalcas paniculata L., Mant.: 68 (1767), i.e. M. paniculata; it is also the holotype of M. scandens Hassk., Abl. Naturf. Gesell. Halle 9: 233 (1866), which is thus a superfluous illegitimate name. 
'M. exotica' is perhaps best treated as a cultivar. Also in cultivation is a free-flowering form with more ovate leaves, resembling wild forms in Australia: it is the commonly seen shrub with neat foliage used in modern civic plantings and private gardens. The cultivation of different forms of M. paniculata taken from different parts of its natural range mirrors the situation seen in white cedar, Melia azedarach L. (Meliaceae; see Mabberley 1984).

Murraya exotica L. var. ovatifoliolata Engl. in Engl. \& Prantl, Nat. Pflanzenfam. III, 4: 188 (1896), has an exiguous description: 'mit rundlichen oder eiförmigen Blättchen, im tropische Nordaustralien' and apparently no extant authentic material, but Australian workers have applied this name to the wild plant (i.e. typical M. paniculata), distinguished from the cultivated forms in its straggling habit, rather hairy shoots and broadly oval or ovate leaflets. Two other varieties were distinguished by Swingle (1944), one of them, var. zollingeri (Tanaka) Tanaka, J. Ind. Bot. Soc. 16: 232 (1937), described from Timor, having small leaflets with deflexed margins. In Australia, with very few intermediate exceptions, plants from dry semi-deciduous to deciduous vinethickets tend to be low sprawling shrubs less than $3 \mathrm{~m}$ tall with such leaflets, highly aromatic when crushed (the 'Small Leaves' plant of Brophy et al. (1994) ? = var. zollingeri). Plants from 'less dry' semi-deciduous notophyll forests form small trees with larger less aromatic leaflets ('Big Leaves' of Brophy et al. 1994) and correspond to the M. paniculata s.s. as represented elsewhere in Indomalesia. Whether the two leafforms are genetically or merely phenotypically distinct variants remains to be demonstrated and their relationship to plants in neighbouring territories is not yet fully elucidated.

\section{Acknowledgments}

I am indebted to Tom Hartley for permission to reproduce the figure of Citrus gracilis, to Don Foreman for the transparency of the type of C. glauca and to Stephen Sykes for information on 'Sydney Hybrid'. Anne Sing provided logistic support in the early part of the work on Aurantioideae, which was initiated in Oxford, and Alistair Hay (Sydney) kindly read through and commented on an early draft of this paper. I am also grateful to Anna Hallett and Miguel Garcia (Sydney) for their enthusiastic help in getting access to literature not held in Sydney.

\section{References}

Barrett, H.C. (1978) Intergeneric hybridization of Citrus and other genera in cultivar improvement. Proc. Int. Soc. Citriculture 1977, 2: 586-9.

Barrett, H.C. and Rhodes, A.M. (1976) A numerical taxonomic study of affinity relationships in cultivated Citrus and its close relatives. Syst. Bot. 1: 105-136.

Brophy, J.J., Forster, P.I. and Goldsack, R.J. (1994) Diversity in Australian populations of Murraya paniculata: new evidence from volatile leaf oils. Aust. Syst. Bot. 7: 409-418.

Burkill, I.H. (1931) An enumeration of the species of Paramignya, Atalantia and Citrus, found in Malaya. Gard. Bull. Straits Settlem. 5: 212-220 [see also Index, 1-7 (1932)].

Desmond, R. (1995) Kew: the history of the Royal Botanic Gardens. (Harvill: London).

Du Puy, D.J. (1993) Rutaceae [Christmas Island]. Flora of Australia 50: 299-306. (Australian Government Publishing Service: Canberra).

Fang, D. and Zhang, W.C. (1994) Intra- and intergeneric relationships of Poncirus polyandra: investigation of leaf isozymes. Proc. Int. Soc. Citriculture 1992, 1: 229-231.

Hiroe, M. (1974) The Forest-plant Hist[o]ry on Japanese Islands I. (Kyoto University: Kyoto).

Mabberley, D.J. (1984) A monograph of Melia in Asia and the Pacific: the history of white cedar and Persian lilac. Gard. Bull. Singapore 37: 49-64. 
Mabberley, D.J. (1992) Robert Mudie (1777-1842) and Australian botany, or The saga of the Black Bean. Austral. Syst. Bot. Soc. Newsletter 70: 13-15.

Mabberley, D.J. (1997) A classification for edible Citrus. Telopea 7: 167-172.

Pedley, L. (1987) Paramignya Wight (Rutaceae: Citreae) in Australia. Austrobaileya 2: 416.

Rahman, M.M. and Nito, N. (1994) Phylogenetic relationships among the "true citrus trees" by glutamate oxaloacetate transaminase isozymes analysis. J. Jap. Soc. Hort. Sci. 62: 755-760.

Scora, R.W. and Kumamoto, J. (1983) Chemotaxonomy of the genus Citrus. Pp. 343-351 in P.G. Waterman and M.F. Grundon (eds), Chemistry and Chemical Taxonomy of the Rutales. (Academic Press: London).

Stone, B.C. (1985) New and noteworthy Paleotropical species of Rutaceae. Proc. Acad. Nat. Sci. Philadelphia 137: 213-228.

Swingle, W.T. (1944, '1943') Vol. 1. The history, botany and breeding. In H.J. Webber and L.D. Batchelor (eds), The Citrus Industry, 3 vols. (California Univ. Press: Berkeley \& Los Angeles).

Swingle, W.T. and Robinson, T.R. (1923) Two important new types of citrous hybrids for the home garden - citrangequats and limequats. J. Agric. Res. 23: 229-238 plus 4 plates.

Vardi, A., Arzee-Gonen, P., Frydman-Shani, A., Bleichman, S. and Galun, E. (1989) Protoplastfusion-mediated transfer of organelles from Microcitrus into Citrus and regeneration of novel alloplasmic trees. Theor. Appl. Genetics 78: 741-7.

Winters, H.F. (1976) Microcitrus papuana, a new species from Papua New Guinea (Rutaceae). Baileya 20: 19-24. 